\title{
Pembelajaran Take AND Give dalam Upaya MengembangKan KEMAMPUAN PEMAHAMAN KonSEP MATEMATIS
}

\author{
Irena Puji Luritawaty \\ Program Studi Pendidikan Matematika, IPI Garut \\ Jl. Pahlawan No. 32 Sukagalih, Garut, Jawa Barat, Indonesia \\ irenapuji@yahoo.com
}

\begin{abstract}
Abstrak
Latar belakang penelitian ini yaitu permasalahan masih rendahnya kemampuan pemahaman konsep matematis pada mahasiswa. Tujuan dari penelitian ini yaitu untuk mengetahui efektifitas pembelajaran take and give dalam upaya mengembangkan kemampuan pemahaman konsep matematis pada mahasiswa. Adapun populasi dalam penelitian ini yaitu mahasiswa tingkat III pada salah satu perguruan tinggi swasta di kabupaten Garut, dengan sampel yaitu mahasiswa tingkat IIIA dan IIIB masing-masing sebanyak 22 orang. Instrumen dalam penelitian ini yaitu berupa tes kemampuan pemahaman konsep matematis dalam bentuk pretest dan posttest. Analisis data yang dilakukan terhadap hasil pretest dan posttest yaitu diawali dengan uji normalitas, kemudian uji homogenitas dan uji-t. Hasil penelitian ini secara garis besar menunjukan bahwa terdapat perbedaan kemampuan pemahaman konsep matematis antara mahasiswa yang memperoleh pembelajaran take and give dan yang memperoleh pembelajaran ceramah biasa, dimana mahasiswa yang memperoleh pembelajaran take and give memperoleh hasil akhir kemampuan pemahaman konsep matematis yang lebih baik daripada yang memperoleh pembelajaran ceramah biasa. Hal ini menunjukkan bahwa pembelajaran take and give dapat secara efektif mengembangkan kemampuan pemahaman konsep matematis.

Kata Kunci: Pembelajaran Take and Give, Kemampuan Pemahaman Konsep Matematis
\end{abstract}

\begin{abstract}
The background of this research is based on the low level of student's ability in understanding mathematical concepts. The purpose of this study is to determine the effectiveness of learning take and give in an effort to develop the ability to understand mathematical concepts in students. The population in this study are third-grade students at one private college in Garut district, with a sample of students IIIA and IIIB. Instruments in this research is a test of ability to comprehend mathematical concepts in the form of pretest and posttest. Analysis of data conducted on the pretest and posttest results is started with the normality test, then homogeneity test and t-test. The results of this study broadly indicate that there is a difference in the ability of understanding mathematical concepts between students who receive learning take and give and who get the ordinary lecture learning, where students who get learning take and give gain the end of the ability of understanding the concept of mathematical better than those who obtained ordinary lecture lessons. This suggests that take and give learning can effectively develop the ability to understand mathematical concepts.
\end{abstract}

Keyword: Take and Give Learning, Understand Mathematical Concept Skills 
http://journal.institutpendidikan.ac.id/index.php/mosharafa

\section{Pendahuluan}

Matematika merupakan salah satu mata pelajaran yang sangat penting. Hal ini disebabkan matematika memiliki fungsi dan kegunaan dalam kehidupan seharihari dan memiliki peranan penting bagi mata pelajaran yang lain (Nuraeni dan Luritawaty, 2017: 442). Matematika juga merupakan salah satu bagian penting dalam upaya menguasai dan menciptakan teknologi di masa depan (Depdiknas: 2006). Namun, pencapaian prestasi matematika Indonesia masih rendah di mata dunia. Fakta tersebut berdasarkan berita edukasi online yaitu bincang edukasi hasil TIMSS 2011. Hasil tersebut menunjukan bahwa persentase pencapaian siswa Indonesia dalam bidang matematika pada kategori rendah, sedang, tinggi, dan lanjut, berturut-turut adalah $43 \%, 15 \%, 2 \%$ dan $0 \%$, dengan rangking ke 36 dari 49 negara. Hasil serupa juga dapat dilihat dari hasil tes Programme for International Student Assessment (PISA) tahun 2015 yang diikuti oleh siswa berumur 15 tahun di bidang matematika, sains dan membaca, bahwa dibanding siswa-siswa lain di dunia, kemampuan siswa Indonesia masih rendah. Indonesia berada di peringkat 69 dari 76 negara yang berpartisipasi dalam tes.

Peningkatan prestasi matematika dapat dilakukan dengan berbagai cara, diantaranya yaitu memaksimalkan penguasaan berbagai kemampuan penting yang terdapat di dalam matematika melalui kegiatan pembelajaran. Salah satu kemampuan penting dalam pembelajaran matematika berdasarkan KTSP (Kurikukum

Tingkat Satuan Pendidikan) yaitu kemampuan pemahaman konsep matematis. Pemahaman konsep matematis adalah suatu proses pengamatan kognisi yang tak langsung dalam menyerap pengertian dari konsep/teori yang akan dipahami, mempertunjukkan kemampuannya di dalam menerapkan konsep/teori yang dipahami pada keadaan dan situasi-situasi yang lainnya. Pemahaman konsep matematis juga berarti suatu kemampuan memahami konsep, membedakan sejumlah konsep-konsep yang saling terpisah, serta kemampuan melakukan perhitungan secara bermakna pada situasi atau permasalahan-permasalahan yang lebih luas (Kurniawan, 2009). Adapun indikator pemahaman matematis menurut Kilpatrick dan Findell (dalam Gunawan, 2013), yaitu : kemampuan menyatakan ulang konsep yang telah dipelajari, kemampuan mengklasifikasikan objekobjek berdasarkan dipenuhi atau tidaknya persyaratan yang berbentuk konsep tersebut, kemampuan menerapkan konsep secara algoritma, kemampuan memberikan contoh dan kontra contoh dari konsep yang telah dipelajari, kemampuan menyajikan konsep dalam berbagai macam bentuk representatif matematika, kemampuan mengaitkan berbagai konsep matematika, dan kemampuan mengembangkan syarat perlu dan syarat cukup suatu konsep.

Kemampuan pemahaman konsep matematis dipandang perlu untuk 
dikembangkan dengan baik karena menjadi dasar dalam penguasaan suatu konsep. Siswa yang memiliki kemampuan pemahaman konsep yang baik akan mampu menggunakan algoritma secara luwes, akurat, efisien, dan tepat dalam pemecahan masalah. Hal tersebut akan berimplikasi pada penguasaan matematika secara umum sesuai dengan yang diharapkan. Selain itu, kemampuan pemahaman konsep matematis juga perlu dikembangkan lagi karena berdasarkan beberapa hasil penelitian yang telah dilakukan, ditemukan fakta bahwa pencapaian kemampuan tersebut masih rendah.

Afrilianto (2012) menyimpulkan rendahnya kualitas pemahaman konsep matematika siswa disebabkan oleh proses pembelajaran dimana guru terlalu berkonsentrasi pada latihan soal yang bersifat prosedural sehingga tidak memungkinkan siswa cepat memperoleh makna dari kegiatan pembelajaran. Dalam penelitian tersebut ditemukan kesalahan konsep siswa dalam materi aljabar. Beberapa siswa tidak dapat membedakan antara penyelesaian persamaan $3 x=6$ dengan $3+x=6$. Hal ini disebabkan rendahnya pemahaman konsep siswa terhadap materi operasi aljabar. Selain itu, rendahnya kemampuan pemahaman konsep juga terlihat dari hasil studi pendahuluan yang dilakukan dalam penelitian tersebut terhadap kemampuan pemahaman konsep. Dari hasil studi pendahuluan ditemukan beberapa penyebab rendahnya tingkat pemahaman konsep siswa, antara lain: (1) siswa cenderung menghafal konsep sehingga menyebabkan siswa mudah lupa terhadap materi yang dipelajarinya; (2) siswa tidak terbiasa dengan soal-soal non-rutin, siswa lebih tertarik menyelesaikan soal yang seperti dicontoh saja.

Permasalahan masih belum berkembangnya kemampuan pemahaman konsep matematik dapat diatasi dengan meningkatkan kerjasama antara pendidik dan peserta didik dalam proses pembelajaran. Menurut Russeffendi (2006: 156): "Keberhasilan proses mengajar matematika tidak terlepas dari persiapan siswa dan persiapan guru. Siswa yang siap untuk belajar matematika akan merasa senang dan dengan penuh perhatian mengikuti pelajaran tersebut. Oleh karena itu guru harus berupaya memelihara dan mengembangkan minat atau kesiapan belajar siswanya. Menghadapi hal tersebut, guru perlu melakukan berbagai upaya, diantaranya dengan menggunakan model pembelajaran yang tepat dalam melakukan proses pembelajaran dan mengaktifkan siswa agar tetap berminat dan mau memusatkan perhatian pada tugas-tugas matematika". Adapun model pembelajaran yang diharapkan dapat mengembnagkan kemampuan pemahaman konsep matematis yaitu model pembelajaran take and give.

Take and Give secara etimologis berarti mengambil dan memberi. Maksud Take and Give dalam model pembelajaran kooperatif adalah dimana peserta didik 
mengambil dan memberi pelajaran pada peserta didik yang lainnya, sehingga diharapkan peserta didik dapat menguasai lebih banyak materi pelajaran dengan mengajarkan pada peserta didik lain. Mengajar teman sebaya memberikan kesempatan kepada peserta didik untuk mempelajari sesuatu yang baik pada waktu yang sama saat ia menjadi narasumber bagi yang lain (Yulietmi, 2013). Beberapa komponen penting dalam model pembelajaran take and give yaitu penguasaan materi melalui kartu keterampilan bekerja berpasangan dan sharing informasi, serta evaluasi yang bertujuan untuk mengetahui pemahaman atau penguasaan siswa terhadap materi yang diberikan di dalam kartu dan kartu pasangannya (Huda, 2013:242).

Rangkaian penyajian data dalam model pembelajaran take and give diawali dengan pembagian dua kelompok besar, masing-masing kelompok diberikan kartu yang di dalam kartu itu sendiri ada catatan yang harus dikuasai atau dihafal oleh masing-masing kelompok. Kemudian siswa dalam kelompok tersebut berbagi dengan siswa kelompok lainnya untuk bertukar pengetahuan yang ada padanya sesuai dengan yang didapatnya dikartu, lalu kegiatan pembelajaran diakhiri dengan mengevaluasi siswa dengan menanyakan pengetahuan yang ada padanya dan yang dia terima dari pasangannya (Huda, 2013).

Dengan kondisi siswa yang sebagian memiliki tingkat pemahaman dan keaktifan yang rendah, maka model pembelajaran Take and Give diharapkan mampu meningkatkan semangat siswa dalam memahami konsep matematika dengan saling memberi dan menerima informasi materi sesama siswa. Siswa yang tidak mempunyai kemauan untuk bertanya kepada guru ketika tidak memahami konsep matematika tersebut dapat langsung bertanya kepada siswa yang mempunyai kemampuan pemahaman konsep matematis yang baik. Hal tersebut berkaitan dengan dengan indikator kemampuan pemahaman konsep matematis yaitu kemampuan menyatakan ulang konsep yang sudah dipelajari, menyajikan konsep dalam berbagai representasi matematika, menerapkan konsep algoritma, dan mengaplikasikan konsep atau algoritma pemecahan masalah.

Berdasarkan uraian di atas, penulis merasa perlu untuk melakukan penelitian terhadap permasalahan terkait. Adapun judul penelitian yang dipilih yaitu "Pembelajaran Take and Give dalam Upaya Mengembangkan Kemampuan Pemahaman Konsep Matematis", dengan rumusan masalah yaitu "Apakah kemampuan pemahaman konsep matematis siswa yang memperoleh pembelajaran Take and Give lebih baik daripada siswa yang memperoleh pembelajaran ceramah biasa?". Adapun hipotesisnya yaitu kemampuan pemahaman konsep matematis mahasiswa yang memperoleh pembelajaran Take and Give lebih baik daripada mahasiswa yang memperoleh pembelajaran ceramah biasa. 


\section{Metode}

Metode yang digunakan dalam penelitian ini yaitu metode kuasi eksperimen. Sampel yang digunakan dalam penelitian ini terdiri dari dua kelompok yaitu kelompok kontrol dan kelompok eksperimen. Kelompok kontrol menggunakan pembelajaran ceramah biasa, sedangkan kelompok eksperimen menggunakan pembelajaran take and give. Adapun desain yang digunakan dalam penelitian ini yaitu berbentuk pretestposttest control group design (Russefendi, 2005: 52), sebagai berikut:

Kelompok Eksperimen Kelompok Kontrol

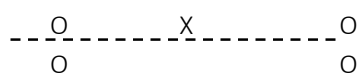

Keterangan:

O: Pretest dan Posttest

$\mathrm{X}$ : Perlakuan terhadap kelompok eksperimen berupa pembelajaran take and give

Penelitian ini dilaksanakan di salah satu perguruan tinggi swasta dikabupaten Garut pada bulan Desember 2017. Adapun populasinya yaitu mahasiswa tingkat III tahun pelajaran 2017-2018, dengan sampel yaitu mahasiswa tingkat IIIA dan IIIB masing-masing sebanyak 22 orang.

Data dalam penelitian ini diperoleh dari data tes awal kemampuan pemahaman konsep matematis (pretest) dan tes akhir kemampuan pemahaman konsep matematis (posttest) dari kelompok kontrol dan eksperimen. Data yang diperoleh kemudian dianalisis dengan uji statistik berbantuan SPSS 18.0. Analisis data yang dilakukan terhadap hasil pretest dan posttest yaitu uji normalitas, kemudian dilanjutkan dengan uji homogenitas, dan diakhiri dengan uji-t.

\section{Hasil dan Pembahasan}

Hasil penelitian berupa data hasil pretest dan posttest diolah secara statistik deskriptif dan inferensi, dengan tujuan untuk mengetahui pencapaian kemampuan pemahaman konsep matematis antara kelas kontrol dan kelas eksperimen. Data yang diperoleh dari hasil pretest dan posttest secara umum adalah sebagai berikut:

Tabel 1.

Data Statistik Skor Kemampuan Pemahaman Konsep Matematis

\begin{tabular}{|cccccc|}
\hline \multirow{2}{*}{ Variabel } & \multirow{2}{*}{ Data Statistik } & \multicolumn{2}{c}{ Kelas Kontrol } & \multicolumn{2}{c|}{ Kelas Eksperimen } \\
\cline { 2 - 6 } & & Pretest & Posttest & Pretest & Posttest \\
\hline Kemampuan & $N$ & 22 & 22 & 22 & 22 \\
\cline { 2 - 6 } $\begin{array}{c}\text { Pemahaman } \\
\text { Konsep }\end{array}$ & $\mathrm{X}_{\max }$ & 45 & 90 & 35 & 100 \\
\cline { 2 - 6 } Matematis & $\mathrm{X}_{\min }$ & 24,41 & 63,39 & 23,90 & 81,49 \\
\cline { 2 - 6 } & $\bar{x}$ & 8,84 & 20,82 & 5,43 & 13,39 \\
\hline
\end{tabular}

Dilihat dari tabel 1, dapat diketahui bahwa nilai rerata pretest kemampuan pemahaman konsep matematis kelas kontrol sebesar 24,41 dan kelas eksperimen sebesar 23,90. Selisih rerata antara kedua kelas tersebut yaitu 0,51. 
Jika dilihat dari rerata pretest, kelas kontrol mempunyai nilai yang sedikit lebih unggul. Akan tetapi, karena selisihnya sangat kecil maka dapat dipandang bahwa tidak terdapat perbedaan kemampuan awal pemahaman konsep matematis antara kedua kelas. Namun, jika dilihat dari hasil nilai rerata posttest, tampak terjadi perbedaan yang cukup signifikan. Kelas kontrol mempunyai rerata sebesar 63,39 dan kelas eksperimen sebesar 81,49. Dari kedua nilai rerata tersebut diperoleh selisih yang cukup besar yaitu 18,1 untuk keunggulan kelas eksperimen. Berdasarkan data tersebut dapat diketahui bahwa rerata kemampuan akhir pemahaman konsep matematis kelas eksperimen lebih baik daripada kelas kontrol.

\section{A. Uji Statistik Data Hasil Pretest Kemampuan Pemahaman Konsep Matematis}

Uji statistik pada data hasil pretest diawali dengan uji normalitas menggunakan uji Shapiro-Wilk, dengan hasil sebagai berikut:

Tabel 2.

Hasil Uji Normalitas Data Pretest Kemampuan Pemahaman Konsep Matematis

Tests of Normality

\begin{tabular}{|c|r|r|r|r|r|r|}
\hline \multirow{2}{*}{} & \multicolumn{3}{|c|}{ Kolmogorov-Smirnov $^{\text {a }}$} & \multicolumn{3}{c|}{ Shapiro-Wilk } \\
\cline { 2 - 7 } & Statistic & df & Sig. & Statistic & \multicolumn{1}{c|}{ df } & Sig. \\
\hline pretest_kontrol &, 145 & 22 &, $200^{*}$ &, 952 & 22 &, 342 \\
\hline
\end{tabular}

a. Lilliefors Significance Correction

*. This is a lower bound of the true significance.

Tests of Normality

\begin{tabular}{|c|r|r|r|r|r|r|}
\hline \multirow{2}{*}{} & \multicolumn{3}{|c|}{ Kolmogorov-Smirnov $^{\mathrm{a}}$} & \multicolumn{3}{c|}{ Shapiro-Wilk } \\
\cline { 2 - 7 } & Statistic & $\mathrm{df}$ & \multicolumn{1}{c|}{ Sig. } & Statistic & \multicolumn{1}{c|}{ df } & \multicolumn{1}{c|}{ Sig. } \\
\hline pretest_eksperimen &, 147 & 22 &, $200^{*}$ &, 962 & 22 &, 535 \\
\hline
\end{tabular}

a. Lilliefors Significance Correction

*. This is a lower bound of the true significance.

Dilihat dari tabel 2 diketahui bahwa nilai signifikansi (Sig.) kelas kontrol sebesar 0,342, sedangkan kelas eksperimen sebesar 0,535. Oleh karena kriteria penerimaan Ho yaitu jika nilai sig $>0,05$, maka nilai sig data pretest kelas kontrol dan kelas eksperimen berada di daerah penerimaan Ho (sig=0,342>0,05 dan sig $=0,535>0,05)$. Hal tersebut berarti pada taraf kepercayan 95\% skor pretest kemampuan pemahaman konsep matematis pada kelas kontrol dan eksperimen berdistribusi normal. Adapun uji statistik berikutnya yang digunakan yaitu uji homogenitas dengan uji Levene (karena kedua data hasil pretest berdistribusi normal). Berikut disajikan hasil uji homogenitas data pretest. 
Tabel 3.

Hasil Uji Homogenitas dan Uji-t Data Pretest Kemampuan Pemahaman Konsep Matematis

\begin{tabular}{|c|c|c|c|c|}
\hline \multicolumn{5}{|c|}{ Independent Samples Test } \\
\hline & & & \multicolumn{2}{|c|}{ pretest } \\
\hline & & & $\begin{array}{c}\text { Equal } \\
\text { variances } \\
\text { assumed }\end{array}$ & $\begin{array}{c}\text { Equal } \\
\text { variances not } \\
\text { assumed }\end{array}$ \\
\hline \multirow{2}{*}{$\begin{array}{l}\text { Levene's Test for Equality } \\
\text { of Variances }\end{array}$} & \multirow{2}{*}{\multicolumn{2}{|c|}{$\begin{array}{l}F \\
\text { Sig. }\end{array}$}} & 3,138 & \\
\hline & & &, 084 & \\
\hline \multirow{7}{*}{$\begin{array}{l}\text { t-test for Equality of } \\
\text { Means }\end{array}$} & \multicolumn{2}{|l|}{$t$} & ,231 & ,231 \\
\hline & \multicolumn{2}{|l|}{ df } & 42 & 34,862 \\
\hline & \multicolumn{2}{|l|}{ Sig. (2-tailed) } & ,818 & ,819 \\
\hline & \multicolumn{2}{|l|}{ Mean Difference } &, 51136 &, 51136 \\
\hline & \multicolumn{2}{|l|}{ Std. Error Difference } & 2,21242 & 2,21242 \\
\hline & \multirow{2}{*}{$\begin{array}{l}95 \% \text { Confidence Interval } \\
\text { of the Difference }\end{array}$} & Lower & $-3,95348$ & $-3,98072$ \\
\hline & & Upper & 4,97621 & 5,00345 \\
\hline
\end{tabular}

Dilihat dari tabel 3, diketahui bahwa nilai signifikansi (Sig.) uji Levene sebesar 0,084 . Nilai tersebut lebih besar dari 0,05 atau sig $>0,05$. Berdasarkan kriteria jika nilai sig > 0,05 maka Ho diterima, dan nilai sig 0,084 > 0,05 sehingga varians skor pretest kemampuan pemahaman konsep matematis kedua kelas homogen. Selanjutnya, karena data homogen, maka uji statistik berikutnya yaitu uji-t. Berdasarkan tabel 3, dapat dilihat bahwa nilai signifikansi (Sig.) uji-t yaitu sebesar 0,818 (lebih besar dari 0,05) atau dengan kata lain sig $>0,05$, sehingga berdasarkan kriteria pengujian di atas maka $\mathrm{H}_{0}$ diterima atau tidak terdapat perbedaan rerata skor pretes kemampuan pemahaman konsep matematis antara mahasiswa di kelas kontrol dan di kelas eksperimen. Hal tersebut berarti pada tingkat kepercayaan 95\%, tidak terdapat perbedaan kemampuan awal pemahaman konsep matematis antara mahasiswa di kelas kontrol dan di kelas eksperimen.

\section{B. Uji Statistik Data Hasil Posttest Kemampuan Pemahaman Konsep Matematis}

Sama halnya dengan uji statistik pada data pretest, uji statistik pada data posttest diawali dengan uji normalitas menggunakan uji Shapiro-Wilk, dengan hasil sebagai berikut:

Tabel 4.

Hasil Uji Normalitas Data Postest Kemampuan Pemahaman Konsep Matematis

Tests of Normality

\begin{tabular}{|l|r|r|r|r|r|r|}
\hline \multirow{2}{*}{} & \multicolumn{3}{|c|}{ Kolmogorov-Smirnov $^{*}$} & \multicolumn{3}{c|}{ Shapiro-Wilk } \\
\cline { 2 - 7 } & Statistic & \multicolumn{1}{c|}{ df } & Sig. & Statistic & \multicolumn{1}{c|}{ df } & \multicolumn{1}{c|}{ Sig. } \\
\hline posttest_kontrol &, 095 & 22 &, $200^{*}$ &, 955 & 22 &, 390 \\
\hline
\end{tabular}

a. Lilliefors Significance Correction

*. This is a lower bound of the true significance. 
Tests of Normality

\begin{tabular}{|l|r|r|r|r|r|r|}
\hline \multirow{2}{*}{} & \multicolumn{3}{|c|}{ Kolmogorov-Smirnov $^{\mathrm{a}}$} & \multicolumn{3}{c|}{ Shapiro-Wilk } \\
\cline { 2 - 7 } & Statistic & \multicolumn{1}{|c|}{$\mathrm{df}$} & \multicolumn{1}{c|}{ Sig. } & Statistic & \multicolumn{1}{c|}{ df } & \multicolumn{1}{c|}{ Sig. } \\
\hline posttest_eksperimen &, 146 & 22 &, $200^{*}$ &, 936 & 22 &, 165 \\
\hline
\end{tabular}

a. Lilliefors Significance Correction

*. This is a lower bound of the true significance.

Dilihat dari tabel 4 diketahui bahwa nilai signifikansi (Sig.) kelas kontrol sebesar 0,390, sedangkan kelas eksperimen sebesar 0,165. Oleh karena kriteria penerimaan Ho yaitu jika nilai sig > 0,05, maka nilai sig data posttest kelas kontrol dan kelas eksperimen berada di daerah penerimaan Ho (sig=0,390>0,05 dan sig $=0,165>0,05)$. Hal tersebut berarti pada taraf kepercayan 95\% skor posttest kemampuan pemahaman konsep matematis pada kelas kontrol dan eksperimen berdistribusi normal. Adapun uji statistik berikutnya yang digunakan yaitu uji homogenitas dengan uji Levene (karena kedua data hasil posttest berdistribusi normal). Berikut disajikan hasil uji homogenitas data posttest.

Tabel 5.

Hasil Uji Homogenitas dan Uji-t Data Postest Kemampuan Pemahaman Konsep Matematis

Independent Samples Test

\begin{tabular}{|c|c|c|c|c|}
\hline & & & \multicolumn{2}{|c|}{ posttest } \\
\hline & & & $\begin{array}{c}\text { Equal } \\
\text { variances } \\
\text { assumed }\end{array}$ & $\begin{array}{c}\text { Equal } \\
\text { variances not } \\
\text { assumed }\end{array}$ \\
\hline $\begin{array}{l}\text { Levene's Test for Equality } \\
\text { of Variances }\end{array}$ & $\begin{array}{l}\mathrm{F} \\
\text { Sig. }\end{array}$ & & $\begin{array}{r}3,642 \\
, 063\end{array}$ & \\
\hline $\begin{array}{l}\text { t-test for Equality of } \\
\text { Means }\end{array}$ & $\begin{array}{l}\text { t } \\
\text { df } \\
\text { Sig. (2-tailed) } \\
\text { Mean Difference } \\
\text { Std. Error Difference } \\
95 \% \text { Confidence Interval } \\
\text { of the Difference }\end{array}$ & $\begin{array}{l}\text { Lower } \\
\text { Upper }\end{array}$ & $\begin{array}{r}-3,430 \\
42 \\
, 001 \\
-18,10227 \\
5,27761 \\
-28,75292 \\
-7,45163\end{array}$ & $\begin{array}{r}-3,430 \\
35,835 \\
, 002 \\
-18,10227 \\
5,27761 \\
-28,80747 \\
-7,39707\end{array}$ \\
\hline
\end{tabular}

Dilihat dari tabel 5, diketahui bahwa nilai signifikansi (Sig.) uji Levene sebesar 0,063 . Nilai tersebut lebih besar dari 0,05 atau sig $>0,05$. Berdasarkan kriteria jika nilai sig > 0,05 maka Ho diterima, dan nilai sig 0,084>0,05 sehingga varians skor pretest kemampuan pemahaman konsep matematis kedua kelas homogen. Selanjutnya, karena data homogen, maka uji statistik berikutnya yaitu uji-t. Berdasarkan tabel 5, dapat dilihat bahwa nilai signifikansi (Sig.) uji-t yaitu sebesar 0,001 (lebih kecil dari 0,05) atau dengan kata lain sig $<0,05$, sehingga berdasarkan 
kriteria pengujian di atas maka $\mathrm{H}_{0}$ ditolak atau rerata skor posttest kemampuan pemahaman konsep matematis mahasiswa kelompok eksperimen lebih baik daripada kelompok kontrol. Hal tersebut berarti bahwa pada tingkat kepercayaan 95\%, kemampuan akhir pemahaman konsep matematis mahasiswa yang memperoleh pembelajaran take and give lebih baik daripada mahasiswa yang memperoleh pembelajaran ceramah biasa. Hal ini menunjukkan bahwa pembelajaran take and give dapat secara efektif mengembangkan kemampuan pemahaman konsep matematis.

\section{Penutup}

Berdasarkan data dan pengolahan data hasil penelitian yang sudah dilakukan, maka dapat disimpulkan bahwa kemampuan pemahaman konsep matematis mahasiswa yang memperoleh pembelajaran take and give lebih baik daripada mahasiswa yang memperoleh pembelajaran ceramah biasa.

Adapun berdasarkan kesimpulan penelitian, peneliti mengajukan beberapa saran sebagai berikut: 1) Pembelajaran take and give direkomendasikan menjadi alternatif pembelajaran pada mahasiswa dalam upaya mengembangkan kemampuan pemahaman konsep matematis; dan 2) Pada penelitian ini dibahas kemampuan pemahaman konsep matematis, direkomendasikan pada penelitian lainnya untuk mengkaji penerapan pembelajaran take and give pada kemampuan berpikir matematis lainnya.

\section{Daftar Pustaka}

Afrilianto, M. (2012). Pembelajaran Matematika dengan Pendekatan Metaphorical Thinking untuk Meningkatkan Pemahaman Konsep dan Kompetensi Strategis Matematis Siswa. Tesis Pendidikan Matematika Universitas Pendidikan Indonesia. Bandung: Tidak ditebitkan.

Depdiknas. (2006). Kurikulum 2006: Standar Isi Mata Pelajaran Matematika untuk SMP/MTs. Jakarta: Ditjen Dikdasmen.

Gunawan, R.P (2013). Kemampuan Pemahaman Matematik (online). Tersedia:

http://proposalmatematika23.blogspo t.com/2013/05/kemampuanpemahman-matematik.html?m=1

Kurniawan,R. (2009). Kemampuan Pemahaman dan Pemecahan Masalah Matematik Serta Pembelajaran Kontekstual. Skripsi pada Jurusan Pendidikan Matematika STKIP Yasika Majalengka (online). Tersedia: http://rudyks3majalengka.blogspot.in/2009/01/kem ampuan-pemahaman-danpemecahan.html [26 April 2016] Muchlis.A. (2013). Sekali lagi gawat darurat pendidikan. Tersedia: http://www.bincangedukasi.com/seka li-lagi-gawat-darurat-pendidikan/. Nuraeni, R., \& Luritawaty, I. P. (2017). Perbandingan Kemampuan 
Pemahaman Matematis Siswa Antara

Yang Menggunakan Pembelajaran

Inside-Outside-Circle Dengan

Konvensional. Mosharafa: Jurnal

Pendidikan Matematika. 6(3):442.

Russefendi, H. E.T. (2005). Dasar-Dasar

Penelitian Pendidikan \& Bidang Non-

Eksakta Lainnya. Bandung: Tarsito.

Russefendi, H. E.T. (2006). Pengantar

kepada Membantu Guru

Mengembangkan Kompetensinya

dalam Pengajaran Matematika untuk

Meningkatkan CBSA. Bandung:

Tarsito.

Yulietmi,I. (2013). Model Pembelajaran

Take And Give (online). Tersedia:

http://dhamma-

link.blogspot.co.id/2013/05/model-

pembelajaran-take-and-give.html [24

April 2016]

\section{Riwayat Hidup PENULIS}

Irena Puji Luritawaty, M.Pd.

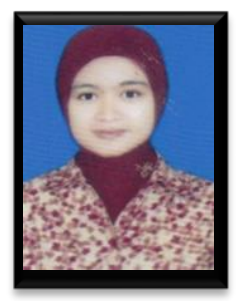

Lahir di Tangerang, 30 April 1988. Staf pengajar di Sekolah Tinggi Keguruan dan Ilmu Pendidikan Garut. Studi S1 Pendidikan Matematika Sekolah Tinggi Keguruan dan Ilmu Pendidikan Garut, lulus tahun 2010; S2 Pendidikan Matematika Universitas Pendidikan Indonesia, lulus tahun 2014. 